\title{
Recenzja \\ Jolanta Panasiuk: Język a komunikacja $w$ afazji Lublin, Wydawnictwo UMCS 2019
}

Przysyłane mi w ostatnim dwudziestoleciu do recenzji prace doktorskie i habilitacyjne z kilku uczelni pozwoliły mi poznać osiągnięcia badań klinicznych z neurobiologii, stanowiące bogaty materiał empiryczny, niedostępny dla szerszego grona osób zainteresowanych kilkoma dyscyplinami naukowymi. Narastające trudności wydawnicze placówek naukowych - ogólnokrajowych i uczelnianych - ograniczają znacznie dostęp do najnowszych i cennych osiągnięć naukowych. W nieznacznym stopniu wiedza ta jest przekazywana studentom na wykładach z psychologii klinicznej, neuropsychiatrii, logopedii i językoznawstwa, co rzutuje na niskie przygotowanie studentów do pracy $\mathrm{z}$ pacjentami.

Książka Jolanty Panasiuk ma walory, które dotyczą nie tylko bogatego materiału badawczego, lecz także nowoczesnego podejścia do zagadnień opisu zaburzeń mowy u osób po uszkodzeniach lewej półkuli mózgu. Autorka badań wyszła poza ramy lingwistycznej analizy zaburzeń afatycznych z konstatacją miejsca uszkodzenia w ośrodkowym układzie nerwowym, które to podejście dominowało w prowadzonych badaniach klinicznych.

Przedmiotem rozważań Autorki nie jest jedynie afazja, lecz człowiek z poważnym defektem mowy. Jako jedna z pierwszych w kraju podjęła kierunek badań zainicjowany przez Olivera Sacksa w 1979 roku w odniesieniu do pacjentów psychiatrycznych w Anglii i Aleksandra R. Łuriję w Rosji z początkiem lat siedemdziesiątych ubiegłego wieku w odniesieniu do chorych neurologicznie.

Autorka w badaniach odeszła od statycznego ujęcia afazji i spojrzała na zjawisko dynamicznie, w ujęciu rozwojowym. To pozwoliło jej opisać osoby z uszkodzeniami mózgu, które podejmują próby radzenia sobie w codziennych sytuacjach życiowych w przezwyciężaniu trudności w komunikowaniu się z otoczeniem. Opisała również trudności osób chorych w spostrzeganiu i ocenie swojej sytuacji, w rozumieniu emocji, motywacji i kontroli własnych zachowań. Dzięki takiemu podejściu konstatowała różnice w zachowaniach wielu chorych niezależnie od natężenia zaburzeń mowy. Materiał empiryczny ma walory naukowe i znacze- 
nie praktyczne dla neuroterapeutów, gdyż wykracza poza terapię logopedyczną. U badanych osób Autorka rozpoznała uwarunkowania organiczne, psychologiczne, socjologiczne, dostosowując metody terapii do poziomu zaburzeń językowych i możliwości komunikacyjnych badanych osób z zachowaniem wymogów psychoterapii.

Autorka jest także świadoma, że stan funkcjonalny badanych osób nie jest trwały, może być modyfikowany przez różne czynniki dodatkowe: organiczne, psychologiczne, sytuacyjne. Dlatego chorych badała w przedziale kilku tygodni lub kilku miesięcy, a nawet lat. Takie podejście ma uzasadnienie w postępach neurofizjologów, psychofarmakologów, neurologów, którzy dokumentują znaczenie plastyczności ośrodkowego układu nerwowego oraz mechanizmów adaptacyjnych, decydujących o kompensacji zaburzeń, co decyduje o skuteczności oddziaływań rehabilitacyjnych logopedów, neuropsychologów i neuropsychiatrów.

Książka Jolanty Panasiuk Język a komunikacja $w$ afazji spełnia naukowe, praktyczne i edukacyjne potrzeby szerokiego grona czytelników zainteresowanych zjawiskiem afazji i sytuacją osób zmagających się z tym zaburzeniem.

dr hab. Marceli Klimkowski psycholog kliniczny specjalista neuropsychologii drugiego stopnia emerytowany profesor UMCS w Lublinie 